\section{Institute files for patents on first Japanese sequences}

Tokyo. Japan has joined the rush to patent human genes on the basis of results of rapid cDNA sequencing. Last week, several Japanese newspapers revealed that Sagami Chemical Research Centre, a privately funded institute just outside Tokyo, has

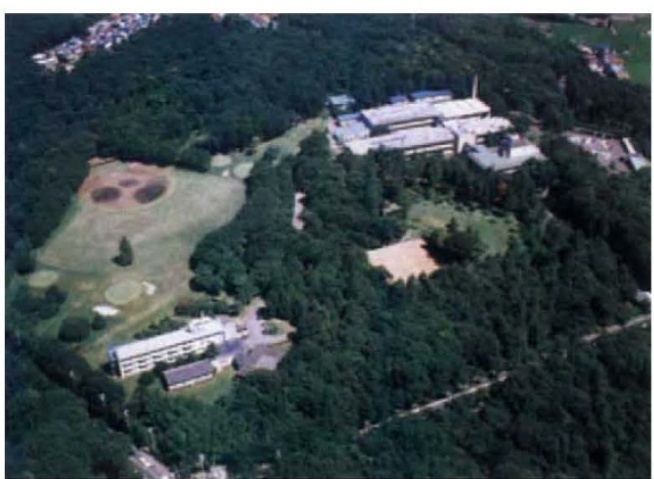

Aerial view of the Sagami centre.

filed patent applications in Japan for about 60 human genes sequenced with a new cDNA technique.

The Sagami centre has applied for patents based on partial sequences of full-length cDNA clones for which some characteristics of gene function have been inferred. Its approach differs from that taken by the US National Institutes of Health (NIH) and Britain's Medical Research Council (MRC), which do not know the functions of many of the thousands of fragments of cDNA clones of human genes for which they are seeking patents.
The centre's move to patent human genes runs counter to a general policy among Japan's genome researchers not to patent the results of gene sequencing projects (see Nature 356, 181; 1992). But the Sagami centre is an unusual organization that depends on patent royalties to fund nearly half of its research (see below) and "the policy of our institute is that we should apply for a patent if we get patentable results", says Seishi Kato, the leader of the group at the Sagami centre.

Kato is one of the early proponents of the cDNA approach to human genome research, and he has developed his own technique to synthesize full-length cDNA rather than using cDNA fragments, the approach applied by NIH, MRC and many other groups around the world. But Kato has only a small semi-automated system of two US-made sequencers and two Seiko robots that at best can sequence 20 kilobases of cDNA a day.

"Sequencing is the rate-limiting step", says Kato, which explains in part why the number of genes for which the centre has made patent applications is so small compared with NIH and MRC.

Kato declined to reveal details of the patent applications. A reporter for the Nikkei Shimbun, Japan's leading financial daily, learned of the patent filings during a series of routine visits to Kato's laboratory.

Although unwilling to talk about the patents, Kato did say that the use of fulllength cDNA rather than random fragments

\section{Sagami keeps the mix boiling}

Tokyo. The Sagami Chemical Research Centre, which has filed Japan's first applications for patents on human genes (see above), is a unique and, by Japanese standards, unusually dynamic research organization.

Established as a foundation in 1963 with backing from the Industrial Bank of Japan and 25 sponsors, including Hitachi, Nissan Motor Co., Tokyo Electric Power Co. and Nippon Steel, the centre has a rapid turnover of researchers. "Most only stay 5 to 10 years and the average age is only 32 or $33^{\prime \prime}$, says Akiyoshi Wada, one of the centre's directors.

Recruits are not offered permanent positions, an unusual policy for a country where lifetime employment is the norm. Rather, their performance is assessed after three years by the head of the institute and board of directors, and those judged good enough get a permanent post.

The centre has received several patents in the past two decades, most of them for organic chemicals, and 40 per cent of the center's $¥ 1,400$ million (US $\$ 11.7$ million) annual budget comes from patent royalties. Although the centre was established to "link chemistry and industry" and is dominated by organic chemists, its 100 researchers now include many biologists working on protein engineering, CDNA, enzymes and anti-cancer drugs.

D.S. allows him to target key parts of the clone for sequencing. He then compares these sequences with sequences on computer databases and is able to infer some of the characteristics of the proteins produced by the genes he has sequenced.

Kato says he is also able to produce proteins in vitro and in vivo directly from his full-length cDNA clones, something that in the case of random cDNA fragments can be done only after screening with probes. But his work on translation and characterization of proteins is still under way and the claims for gene function in the patent applications are based only on comparisons of his sequence data with computer databases. Even so, Kato believes that his partial sequences of full-length cDNA are patentable "even if gene function is unknown".

Kenichi Matsubara of Osaka University, leader of Japan's human genome project, does not expect researchers at Japan's universities and national laboratories to follow the Sagami centre's lead in patenting cDNA sequences. He says that there are no patent lawyers in Japan's government laboratories and this "tremendous defect in the present system" means that government researchers have to team up with private companies if they want to patent discoveries. But government regulations make that difficult, he says, adding that "unlike their US counterparts, not many Japanese companies seem willing to pay for patenting just sequences".

David Swinbanks

\section{Research heads discuss impact of Framework}

Munich. The heads of Europe's national research organizations have begun to meet informally to discuss the effect on their national efforts of a growing European science programme.

The European Communities (EC) will spend around ECU14.7 billion (US\$19 billion) in its 1994-1998 Framework programme. Most of this will be spent on applied research, but the magnitude guarantees that it will exert an influence on national programmes as well.

After meeting for the first time last month in Bonn, the heads of the national organizations want to continue talking about ways to interact with the EC and to share in the development of Europe-wide science and science policy. The next meeting is planned for next autumn in Britain.

In anticipation of the Maastricht treaty being signed, the research heads want to clarify how subsidiarity - a means to make decisions at the lowest possible level - will affect European and national research policies. They also want to rethink the role of the European Science Foundation.

Alison Abbott 